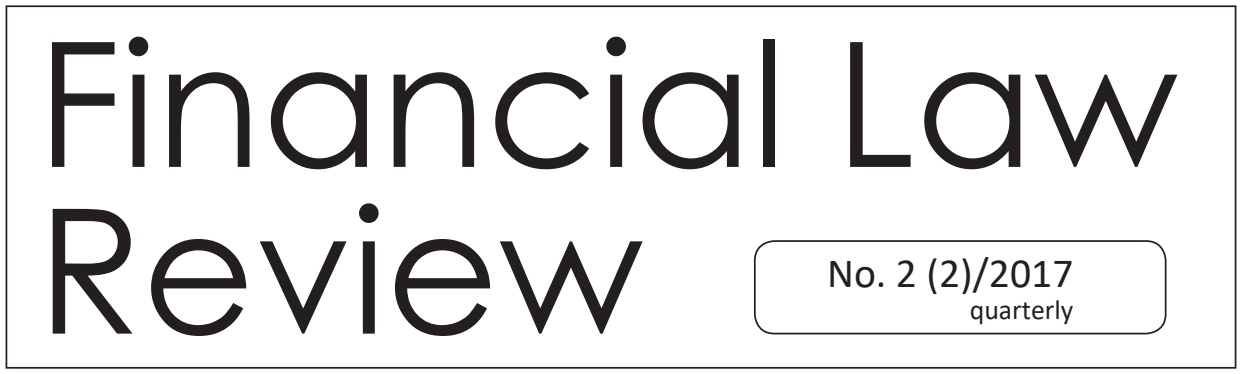

UNIVERSITY OF GDAŃSK • FACULTY OF LAW AND ADMINISTRATION

http://www.ejournals.eu • http://czasopisma.bg.ug.edu.pl

\title{
PRZEWŁASZCZENIE WŁASNOŚCI
} NIERUCHOMOŚCI NA ZABEZPIECZENIE W ASPEKCIE KWALIFIKACJI PODMIOTOWOŚCI PODATKOWOPRAWNEJ NA GRUNCIE PODATKU OD NIERUCHOMOŚCI

Mirostawa Hirsz

\section{Wstęp}

Przewłaszczenie na zabezpieczenie stanowi ukształtowaną przez praktykę gospodarczą formę zabezpieczenia wierzytelności, polegającą na wykorzystaniu prawa własności rzeczy jako „gwarancji” spłaty udzielonych kredytów lub pożyczek. Zabezpieczenie to jest w obrocie cywilnoprawnym dokonywane na podstawie umowy, zaliczającej się - z powodu braku określenia, w treści obowiązujących przepisów prawa, składników przedmiotowo istotnych tej umowy - do tzw. umów nienazwanych.

Stosowanie przewłaszczenia rzeczy na zabezpieczenie wierzytelności - choć budzi wiele kontrowersji w doktrynie - zostało uznane, zarówno przez orzecznictwo Sądu Najwyższego jak i sądów apelacyjnych, za dopuszczalne w ramach zasady 
swobody umów wyrażonej w art. $353^{1}$ kodeksu cywilnego ${ }^{1}$. Zaakceptowane w judykaturze zostały również umowy przewłaszczenia nieruchomości na zabezpieczenie $^{2}$. Zapadłe w tej kwestii orzecznictwo nie zakończyło jednak trwającego w nauce prawa sporu, co do możliwości używania prawa własności rzeczy (w tym nieruchomości) jako narzędzia służącego do zabezpieczania wierzytelności Brak wśród przedstawicieli doktryny konsensusu w tym względzie nie deprecjonuje wszakże celowości dokonania analizy, kto, na skutek zawartych w obrocie prywatnoprawnym umów przewłaszczenia nieruchomości (które to umowy, wobec ich akceptacji przez orzecznictwo, są coraz częściej stosowane w praktyce), jest podatnikiem podatku od nieruchomości, tj. czy jest nim wierzyciel będący właścicielem, czy dłużnik faktycznie władający nieruchomością. Trzeba bowiem zauważyć, że organ podatkowy nie jest władny negować ważności umowy cywilnoprawnej, która funkcjonuje w obrocie prawnym.

Jakkolwiek w literaturze prawniczej dość szeroko zostały wyjaśnione kwestie związane $\mathrm{z}$ charakterem prawnym przewłaszczenia na zabezpieczenie, a także sama jego konstrukcja, niewiele poświęcono uwagi na temat zmian jakie ono powoduje w stanie posiadania przewłaszczonej nieruchomości, w tym w szczególności w zakresie posiadania samoistnego, które zgodnie $\mathrm{z}$ art. 3 ust. 1 pkt 2 oraz art. 3 ust. 3 ustawy o podatkach i opłatach lokalnych ${ }^{4}$, wyznacza podatkowoprawną sytuację osoby fizycznej/prawnej (lub jednostki organizacyjnej nieposiadającej osobowości prawnej) jako podatnika podatku od nieruchomości. W zasadzie bezdyskusyjnie powszechnie przyjęto w doktrynie stanowisko, że dotychczasowy właściciel (dłużnik) zachowuje rzecz w swoim władaniu jako posiadacz zależny, na podstawie ukształtowanego z nowym właścicielem (wierzycielem) wewnętrznego

\footnotetext{
${ }^{1}$ Ustawa z dnia 23 kwietnia 1964 r. - Kodeks cywilny (tekst jedn. Dz. U. z 2017 r. poz. 459, z późn. zm.), dalej jako: k.c.

2 Pomimo pierwotnego negatywnego stanowiska, wyrażonego w wyroku SN z dnia 24 kwietnia 1964 r., sygn. II CR 178/64 (w którym Sąd Najwyższy uznał za niedopuszczalne przeniesienie na zabezpieczenie własności nieruchomości jako naruszające zakaz przenoszenia własności nieruchomości z zastrzeżeniem warunku i terminu), Sąd Najwyższy w późniejszych orzeczeniach (wyrok SN z dnia 29 maja 2000 r., III CKN 246/00, wyrok SN z dnia 8 marca 2002 r., III CKN 748/00, wyrok SN z dnia 28 października 2010 r., II CSK 218/10) opowiedział się za dopuszczalnością tego typu umów. 3 Zob. szerzej P. Żak, O bezprawnym przejmowaniu nieruchomości dłużników, „Prokuratura i Prawo” 2017, nr 1, s. 75 oraz przywołaną tam literaturę, I. Karasek [w:] Prawo bankowe. Komentarz, t. 2, red. F.Zoll, Kraków 2005, s. 183-187oraz przywołaną tam literaturę, J. Pisuliński, Glosa do wyroku SN $z$ dnia 8 marca 2002 r., III CKN 748/00, OSP 2003, nr 3, s. 37, a także, S. Kostecki, Wierzytelność a rzeczowe zabezpieczenia na nieruchomości, Warszawa 2014, s. 31-38.

${ }^{4}$ Ustawa z dnia 12 stycznia 1991 r. o podatkach i opłatach lokalnych (tekst jedn. Dz. U. z 2017 r. poz. 1785, z późn. zm.),dalej jako: u.p.o.l.
} 
stosunku prawnego ${ }^{5}$. Wierzyciel $\mathrm{z}$ kolei, $\mathrm{w}$ zamian za udzieloną pożyczkę lub kredyt, nabywa prawo własności i względem osób trzecich legitymuje się niczym nieskrępowanym władztwem nad nieruchomością ${ }^{6}$. Stanowisko takie zostało także zawarte w większości orzeczeń sądów odnoszących się do tej kwestii ${ }^{7}$. Przyjętej linii orzeczniczej nie podzielił jednak Wojewódzki Sąd Administracyjny w Lublinie, który w wyroku z dnia 13 stycznia 2015 r., I SA/Lu 783/15, powołując cechy charakterystyczne umowy przewłaszczenia na zabezpieczenie, stwierdził, że przewłaszczenie, z powodu wyłącznie jego gwarancyjnego celu, nie prowadzi do zmian w stanie posiadania i zaznaczył przy tym, że strony takiej umowy mogą stosownie do swego uznania określić zakres posiadania przysługującego każdej $\mathrm{z}$ nich.

Przedstawiona w powyższym wyroku, odmienna, w stosunku do tej przyjętej wcześniej w doktrynie i orzecznictwie, koncepcja na temat stanu posiadania zaistniałego po zawarciu umowy przewłaszczenia na zabezpieczenie, jest dobrym przykładem na to, że podjęcie rozważań w tej materii jest w pełni zasadne.

\section{Zasadnicze elementy umowy przewłaszczenia na zabezpieczenie}

Umowy przewłaszczenia nieruchomości na zabezpieczenie, należąc do kategorii umów nienazwanych, konstruowanych na zasadzie swobody kontraktowej, nie posiadają ustawowo zarysowanych elementów istotnych pozwalających na przypisanie im stałych i niezmiennych cech kształtujących treść zobowiązań umownych. Niemniej jednak stały się one konstrukcjami na tyle ujednoliconymi i popularnymi w obrocie, że możliwe jest wyróżnienie charakterystycznych dla nich treści oraz powtarzalnego układu praw i obowiązków. Najogólniej rzecz ujmując, przewłaszczenie na zabezpieczenie polega na przeniesieniu przez dłużnika prawa własności swojej rzeczy na wierzyciela, w celu zabezpieczenia istniejącej wierzytelności, z tym jednak zastrzeżeniem, iż po spłacie wierzytelności powstanie po

\footnotetext{
${ }^{5}$ Zob. J. Gołaczyński, Przeniesienie własności nieruchomości na zabezpieczenie, „Rejent” 1994, nr 5, s. 47, J. Gołaczyński, Przewłaszczenie ruchomości na zabezpieczenie, „Rejent” 1995, nr 1, s. 61 i 64, I. Karasek [w:] Prawo bankowe..., s. 156, S. Kostecki, Wierzytelność a rzeczowe ..., s. 31-38, J. Górecki, Niektóre następstwa i skutki umowy przewłaszczenia na zabezpieczenie, „Rejent” 1997, nr 4, s. 165.

${ }^{6}$ S. Kostecki, Wierzytelność a rzeczowe ..., s. 31-38.

7 Uchwała SN z dnia 10 maja 1948 r., C Prez 18/1948, wyrok SN z dnia 8 marca 2002 r., III CKN 748/00, uchwała SN z dnia 22 kwietnia 2005 r., III CZP 99/04,wyrok WSA w Poznaniu z dnia 10 listopada 2015 r., I SA/Po 750/15, wyrok WSA w Gliwicach z dnia 30 sierpnia 2016 r., I SA/Gl 322/16, wyrok WSA w Warszawie z dnia 4 stycznia 2017 r ., wyrok WSA w Krakowie z dnia 14 lipca 2017 r., I SA/Kr 486/17.
} 
stronie wierzyciela obowiązek powrotnego przeniesienia własności ${ }^{8}$. W zasadzie jest to realizowane poprzez zawarcie dwóch sprzężonych ze sobą umów. Pierwszą jest umowa przenosząca własność z dłużnika na wierzyciela bez jakichkolwiek warunków czy innych zastrzeżeń, druga zaś stanowi umowę zobowiązującą wierzyciela do powrotnego przeniesienia własności pod warunkiem spełnienia wierzytelności ${ }^{9}$.

Cechą charakterystyczną umowy przenoszącej własność na zabezpieczenie (z której wynika atrakcyjność tego typu zabezpieczenia), jest pozostawienie rzeczy we władaniu dłużnika na podstawie innego stosunku prawnego ${ }^{10}$. Dłużnik jest najczęściej, w związku z tym, zobowiązany do ponoszenia wszelkich kosztów i opłat związanych z przewłaszczonym mieniem, a także odpowiedzialny za ewentualne szkody wyrządzone $z$ tytułu sprawowanego posiadania. Wierzyciel podejmuje natomiast zobowiązanie do korzystania z prawa własności w sposób niewykraczający poza granice uzasadnione wykonaniem zabezpieczenia wierzytelności ${ }^{11}$.

Specyfika zabezpieczenia ustanawianego umową przewłaszczenia na zabezpieczenie wiąże się z przekazaniem wierzycielowi tytułu prawnego do majątku dłużnika (służącego jako zabezpieczenie udzielonej pożyczki lub kredytu), przy jednoczesnym dalszym istnieniu zobowiązania dłużnika do zaspokojenia wierzytelności tego, który stał się właścicielem przedmiotu zabezpieczenia. Wierzyciel znajduje się więc w bardzo korzystnej sytuacji, gdyż poza przysługującym mu roszczeniem o spełnienie świadczenia, dysponuje także przejętym majątkiem dłużnika, z którego to roszczenie może zaspokoić12 .

\footnotetext{
8 Zob. J. Gołaczyński, Przewłaszczenie ruchomości..., s. 59, wyrok SN z dnia 8 marca 2002 r., III CKN 748/00.

9 Zob. J. Gołaczyński, Przeniesienie własności..., s. 41,J. Gołaczyński, Przewłaszczenie ruchomości..., s. 59, A. Wójcik, Przewłaszczenie na zabezpieczenie, „Radca Prawny” 1997, nr 5, s. 39.

10 Takim stosunkiem może być np. użyczenie, tj. oddanie rzeczy do bezpłatnego używania przez czas określony, czyli do momentu ziszczenia się warunku zawieszającego. Strony mogą również w inny sposób ukształtować treść stosunku wewnętrznego - J. Gołaczyński, Przeniesienie własności..., s. 40 i 46, J. Gołaczyński, Przewłaszczenie ruchomości..., s. 61 i 64, J. Górecki, Niektóre..., s. 165, K. Smolny, Przewłaszczenie jako zabezpieczenie wierzytelności bankowych, Zeszyty Naukowe Uniwersytetu Szczecińskiego, nr 855, Finanse, Rynki Finansowe, Ubezpieczenia nr 74, t. 1, 2015 s. 561.

11 Zob. stan faktyczny opisany np. w wyrokach: WSA w Lublinie z dnia 13 stycznia 2016 r., I SA/ Lu 783/15, WSA w Gliwicach z dnia 30 sierpnia 2016 r., I SA/Gl 322/16, WSA w Krakowie z dnia 14 lipca 2017 r., I SA/Kr 486/17.

12 H. Zbrzeżna-Cąkała, Kilka uwag na temat umowy przewłaszczenia na zabezpieczenie, NPN 2016, nr 1, s. 47.
} 
Przyjmuje się, że przeniesienie własności rzeczy w celu zabezpieczenia określonej wierzytelności ma inną niż tradycyjna, własną przyczynę przysporzenia, którą jest causa cavendi ${ }^{13}$. Ta odrębność przyczyny przysporzenia sprawia, że inaczej niż np. przy umowie sprzedaży, przewłaszczenie rzeczy w celu zabezpieczenia nie następuje z zamiarem trwałego wyzbycia się jej własności ${ }^{14}$.

Przywrócenie stanu własnościowego, do takiego jaki panował przed zawarciem umowy przewłaszczenia, uzależnione jest jednak od ziszczenia się warunku zawieszającego, jakim jest spełnienie należności przez dłużnika. Tylko wówczas wymagalne stanie się zobowiązanie wierzyciela do powrotnego przeniesienia własności. Do tego zaś czasu zobowiązanie to w niczym nie ogranicza prawa własności wierzyciela, któremu przysługują wszelkie uprawnienia przewidziane w art. 140 k.c. ${ }^{15}$.

Jak zatem widać z powyższego, z nieruchomością poddaną przewłaszczeniu na zabezpieczenie „powiązane” są dwa podmioty: właściciel (wierzyciel) niesprawujący fizycznego władztwa oraz posiadacz (dłużnik) faktycznie władający nieruchomością. W świetle wspomnianych we wstępie okoliczności pojawia się więc pytanie, czy w takim stanie rzeczy dochodzi do zbiegu tytułu własności i posiadania samoistnego nieleżącego po stronie właściciela, co oznaczałoby - zgodnie $\mathrm{z}$ art. 3 ust. 3 u.p.o.l. - konieczność uznania tego posiadacza, a nie właściciela, za podatnika podatku od nieruchomości. Weryfikacja tej kwestii wymaga niewątpliwie odwołania się do znaczenia, użytego we wskazanym powyżej przepisie, sformułowania „posiadacz samoistny”.

\section{Rozumienie pojęć właściciela i posiadacza samoistnego}

Brak zdefiniowania w ustawie podatkowej pojęć właściciela i posiadacza samoistnego, użytych przy określaniu podmiotów podlegających podatkowi od nieruchomości, wskazuje, że wolą ustawodawcy było przejęcie znaczeń tych terminów wykształconych i używanych w prawie cywilnym. Z pewnością konstatacja taka jest uprawniona w świetle zasad racjonalnej polityki ustawodawczej oraz spójności

13 Zob. J. Gołaczyński, Przeniesienie własności..., s. 43, J. Gołaczyński, Przewłaszczenie ruchomości..., s. 64,S. Stępień, Dopuszczalność i sposoby przewłaszczenia na zabezpieczenie we współczesnym obrocie gospodarczym w Polsce, Zeszyty Naukowe Instytutu Administracji AJD w Częstochowie 2012, nr 1, s. 194-195, S. Kostecki, Wierzytelność a rzeczowe..., s. 31-38 wraz z powołanym tam odmiennym poglądem i przywołaną literaturą, wyrok SN z dnia 19 listopada 1992 r., II CRN 87/92.

14 Wyrok SN z dnia 13 maja 2011 r., V CSK 360/10.

15 Wyrok SN z dnia 19 listopada 1992 r., II CRN 87/92, wyrok SN z dnia 13 maja 2011 r., V CSK $360 / 10$. 
sytemu prawa, w myśl których należy unikać wprowadzania pojęć odrębnych dla każdej gałęzi prawa ${ }^{16}$. Prawodawca nie powinien bowiem regulować w danej dziedzinie, w tym przypadku w prawie podatkowym, zagadnień, które są już w systemie unormowane i mogą stanowić właściwy instrument założonych przez niego celów ${ }^{17}$. Odwołując się do pojęcia autonomii prawa podatkowego, nie można pomijać tych systemowych powiązań. Dlatego też wszędzie tam, gdzie prawodawca nie tworzy instytucji i pojęć swoistych dla tego prawa, lecz posługuje się terminami wykształconymi w innych dziadzinach prawa - należy przyjmować takie znaczenie tych terminów jakie zostało wypracowane w macierzystej gałęzi prawa $^{18}$. Odczytanie normatywnej treści danego pojęcia powinno odbywać się wówczas z zastosowaniem wykładni systemowej zewnętrznej.

Niewątpliwie, w przypadku użytych w prawie podatkowym pojęć „własność” i „posiadanie”, ten rodzaj wykładni wymaga odwołania się do przepisów kodeksu cywilnego, stanowiących źródło prawne tychże instytucji. Poza tym tyko ta ustawa zawiera definicje omawianych pojęć. W świetle postulatu spójności systemu prawa nie sposób więc uznać, aby możliwe było nadanie im innego aniżeli cywilistyczne znaczenie.

Zastosowanie rozumienia, zawartych w prawie podatkowym pojęć „własność” i „posiadanie”, zgodnie z ich znaczeniem wykształconym w prawie cywilnym, podkreśla się również w orzecznictwie sądów administracyjnych, w którym zgodnie przyjmuje się, że fakt nieutworzenia w prawie podatkowym odrębnych definicji tych pojęć, powoduje, że należy rozumieć je w sposób uniwersalny, nadany im przez prawo cywilne ${ }^{19}$. Oznacza to tym samym, że wykładnia pojęć „właściciel” czy "posiadacz” wymaga odwołania się do przepisów prawa cywilnego, orzecznictwa sądów powszechnych i Sądu Najwyższego dotyczących tych pojęć, a także do dorobku nauki prawa.

Spośród wskazanych powyżej pojęć, kwestią zasadniczą - dla ustalenia, na której ze stron umowy przewłaszczenia nieruchomości na zabezpieczenie - ciąży obowiązek podatkowy w podatku od nieruchomości, jest skupienie rozważań nie tyle

\footnotetext{
16 Postanowienie Trybunału Konstytucyjnego z dnia 17 kwietnia 2013 r., Ts 352/11.

17 R. Mastalski, Autonomia prawa podatkowego a spójność i zupetność systemu prawa, „Przegląd Podatkowy" 2003, nr 10, s. 15.

${ }_{18}$ R. Mastalski, Autonomia..., s. 15, B. Brzeziński, Prawo podatkowe a prawo cywilne [w:] Prawo podatkowe. Teoria. Instytucje. Funkcjonowanie, red. B. Brzeziński, Toruń 2009, s.407.

19 Np. wyrok NSA (do 2003.12.31) w Łodzi z dnia 18 czerwca 1997 r., I SA/Łd 535/96, wyrok NSA z dnia 9 grudnia 2009 r., II FSK 1043/08, wyrok NSA z dnia 11 września 2014 r., II FSK 917/14, wyrok WSA w Lublinie z dnia 31 maja 2017 r., I SA/Lu 1070/16.
} 
na tym, kto jest właścicielem nieruchomości, lecz ustalenie z jakiego rodzaju posiadaniem mamy do czynienia w przypadku obu stron umowy. Zastrzeżeń nie budzi bowiem kto jest właścicielem przewłaszczonych nieruchomości, którym jest wierzyciel, lecz to po czyjej stronie leży ich posiadanie samoistne. To na tym tle powstają spory pomiędzy właścicielami takich nieruchomości a organami podatkowymi, w których ci pierwsi stoją na stanowisku, iż dłużnicy faktycznie władający nieruchomościami są ich posiadaczami samoistnymi i tym samym podatnikami podatku od nieruchomości ${ }^{20}$.

Jakkolwiek nie budzi wątpliwości, że w przypadku gdy nieruchomość znajduje się $\mathrm{w}$ posiadaniu samoistnym osoby niebędącej jej właścicielem, podatnikiem podatku od nieruchomości jest posiadacz samoistny, co wynika wprost z art. 3 ust. 3 u.p.o.l., należy rozważyć czy rzeczywiście posiadanie sprawowane przez dłużnika przewłaszczonej nieruchomości jest samoistne. W tym celu niezbędne jest odwołanie się - tak jak to zostało wskazane powyżej - do przepisów prawa cywilnego, dorobku nauki prawa oraz orzecznictwa sądów powszechnych i Sądu Najwyższego odnoszących się do posiadania.

\section{Posiadanie}

Punktem wyjścia dla rozważań dotyczących posiadania jest art. 336 k.c., który definiuje ten termin. Wskazany przepis w dosłownym brzmieniu stanowi, że „posiadaczem rzeczy jest zarówno ten, kto nią faktycznie włada jak właściciel (posiadacz samoistny), jak i ten, kto nią faktycznie włada jak użytkownik, zastawnik, najemca, dzierżawca lub mający inne prawo, z którym łączy się określone władztwo nad cudzą rzeczą (posiadacz zależny)”.Wyróżnia on dwa rodzaje posiadania: posiadanie samoistne i posiadanie zależne, które różnią się sposobem władania „jak właściciel” lub „jak mający inne prawo do władania rzeczą”. W poglądach doktryny ${ }^{21}$ i orzecznictwa ${ }^{22}$ odnoszących się do tego przepisu podkreśla się, że na posiadanie składają się dwa elementy: element fizyczny, określany

${ }^{20}$ Np. spory rozstrzygane w wyrokach: WSA w Lublinie z dnia 13 stycznia 2016 r., I SA/Lu 783/15, WSA w Warszawie z dnia 4 stycznia 2017 r., WSA w Krakowie z dnia 14 lipca 2017 r., I SA/Kr 486/17 ${ }^{21}$ Np. A. Stelmachowski, Istota i funkcje posiadania, Warszawa 1958, s. 58, J. Ignatowicz, Ochrona posiadania, Warszawa 1963, s. 51-52; S. Kołodziejski, Istota, treść i rodzaje posiadania, „Palestra” 1966, nr 10/6, s. 16, S. Grzybowski, J. Skąpski, S. Wójcik, Zarys prawa cywilnego, Warszawa 1988, s. 402. A. Kunicki, System prawa cywilnego. Prawo własności i inne prawa rzeczowe, red. J. Ignatowicz, Wrocław-Warszawa-Kraków 1977, s. 830.

22 Np. orzeczenie SN z dnia 14 kwietnia 1961 r., CR 961/60, postanowienie SN z dnia 16 listopada 1998 r., I CKN 888/97, postanowienie SN z 27 dnia listopada 1998 r., III CKN 43/98, wyrok SN z dnia 28 września 2000 r., IV CKN 103/00, uchwała SN z dnia 26 października 2007 r.,III CZP $30 / 07$. 
tradycyjnie jako corpus possessionis lub krótko corpus, oraz element psychiczny, określany jako animus rem sibi habendi, animus possidendi lub krótko jako animus. Elementy te bywają też nazywane jako zewnętrzna i wewnętrzna strona posiadania. Wynikają one z następujących słów ustawy: słowa „kto nią (rzeczą) faktycznie włada” oznaczają element fizycznego władztwa, określenie zaś „jak właściciel”, „jak użytkownik” itp. uwypukla element drugi ${ }^{23}$.

W przypadku elementu „władania rzeczą” (corpus) chodzi o dostrzegalny fakt fizycznego władztwa nad rzeczą, „zatrzymania” rzeczy, jej „używania”, „korzystania"24. Występuje wtedy, gdy dana osoba znajduje się w sytuacji pozwalającej jej na korzystanie z rzeczy w taki sposób, w jaki mogą to czynić osoby, którym przysługuje do rzeczy określone prawo, przy czym nie jest wymagane efektywne korzystanie z rzeczy, wystarczy sama możliwość korzystania, rozumiana jako możność używania tej rzeczy, pobierania z niej pożytków, przekształcenia lub nawet zniszczenia ${ }^{25}$.

Animus oznacza zaś wolę wykonywania względem rzeczy określonego prawa dla siebie albo - inaczej - we własnym imieniu ${ }^{26}$. Rola tego elementu ma doniosłe i decydujące znaczenie w ukierunkowaniu posiadania. Od czynnika woli, czyli wewnętrznej treści posiadania, zależy bowiem, czy mamy do czynienia z posiadaniem samoistnym, zależnym, służebnym, czy może tylko z dzierżeniem. Znaczenie woli posiadacza jest w tym względzie rozstrzygające ${ }^{27}$. Zgodnie z przeważającym poglądem doktryny ${ }^{28}$ oraz jednolitym stanowiskiem orzecznictwa ${ }^{29}$ odczytywanie elementu woli, powinno następować według tzw. teorii obiektywnej, tj. na podstawie zewnętrznych, zamanifestowanych przejawów posiadania.

${ }_{23}$ J. Ignatowicz, K. Stefaniuk, Prawo rzeczowe, Warszawa 2009,s. 318-319, postanowienie SN z dnia 16 listopada 1998 r., I CKN 888/97.

${ }^{24}$ Zob.J. Gołaczyński, Kodeks cywilny. Komentarz, wyd. 7, red. E. Gniewek, P. Machnikowski, Warszawa 2016, s. 583.

25 Zob. np. wyrok SN z dnia 3 czerwca 1966 r., III CR 108/66, wyrok SN z dnia 15 czerwca 1972 r., III CRN 121/72, postanowienie SN z dnia 7 kwietnia 1994 r. III CRN 18/94, uchwała SN z dnia 26 października 2007 r., III CZP 30/07, postanowienie SN z dnia 30 września 2010 r., I CSK 586/09, postanowienie SN z dnia 4 marca 2016 r. I CSK 519/15.

26 J. Ignatowicz, K. Stefaniuk, Prawo..., s. 319.

27 S. Kołodziejski, Istota..., s. 21; postanowienie SN z dnia 28 marca 2000 r., II CKN 879/98, wyrok SN z dnia 28 września 2000 r., IV CKN 103/00, postanowienie SN z dnia 20 czerwca 2012 r., I CSK 561/11, postanowienie SN z dnia 4 grudnia 2015 r., I CSK 988/14.

${ }_{28}$ Zob. szerzej W. Czachórski, Pojęcie i treść posiadania według obowiązującego prawa rzeczowego, NP 1957, nr 5 s. 40, A. Stelmachowski, Istota...., s. 79-86, J. Ignatowicz, Ochrona..., s. 72.

${ }^{29}$ Np. postanowienie SN z dnia 29 września 2004 r., II CK 550/03, uchwała SN z dnia 26 października 2007 r., III CZP 30/07, postanowienie SN z dnia 25 marca 2011 r., IV CK 1/11, wyrok NSA z dnia 12 grudnia 2012 r., II FSK 1806/12, postanowienie SN z dnia 4 grudnia 2015 r., I CSK 988/14. 
Akcentowany przez ustawodawcę - dla odróżnienia pomiędzy posiadaniem samoistnym i zależnym - zakres władania rzeczą, wiążący się z elementem animus, tj. zamiarem władania rzeczą „dla siebie”, może więc obejmować w odmiennych wersjach zamiar władania rzeczą „jak właściciel” (cum animo domini) lub władania rzeczą ,jak mający inne prawo" ${ }^{30}$.

Rozróżnienie w praktyce tych dwóch form władania nastręcza niekiedy trudności. W obu tych rodzajach posiadania występuje bowiem władanie rzeczą „dla siebie", co, z punktu widzenia postronnego obserwatora, dostrzegającego tylko faktycznego użytkownika rzeczy (np. osobę zamieszkującą daną nieruchomość lub prowadzącą działalność gospodarczą), mogłoby - zwłaszcza w świetle domniemania wynikającego $\mathrm{z}$ art. 339 k.c. - każdorazowo prowadzić do uznania osoby faktycznie władającej rzeczą (nieruchomością) za posiadacza samoistnego. Widać więc, że takie zbyt pobieżne spojrzenie prowadziłoby do błędnych wniosków we wszystkich tych przypadkach, w których rzecz została oddana w posiadanie zależne, czyli wówczas gdy posiadanie rzeczy jest sprawowane równocześnie przez posiadacza samoistnego i zależnego. Posiadacz samoistny oddając rzecz w posiadanie zależne traci co prawda bezpośrednią (w sensie fizycznym) władzę nad rzeczą, ale nie odbywa się to kosztem bytu jego posiadania. Zgodnie bowiem z art. 337 k.c. posiadacz samoistny nie traci posiadania przez to, że oddaje drugiemu rzecz $\mathrm{w}$ posiadanie zależne. $\mathrm{W}$ razie przekazania rzeczy w posiadanie zależne nabywca posiadania uzyskuje posiadanie zależne, natomiast zbywca zachowuje posiadanie samoistne. Posiadacz zależny wykonuje wówczas władztwo dla siebie, lecz w sposób podporządkowany posiadaczowi samoistnemu ${ }^{31}$.

Należy w tym miejscu zauważyć, że prawidłowa kwalifikacja rodzaju posiadania, występującego w przypadku, gdy nieruchomością włada osoba niemająca do niej prawa własności, ma niebagatelne znaczenie dla ustalenia podatnika podatku od nieruchomości. Ustawa o podatkach i opłatach lokalnych - w odniesieniu do nieruchomości niestanowiących własności Skarbu Państwa lub jednostki samorządu terytorialnego - obowiązek podatkowy w podatku od nieruchomości wiąże bowiem tylko $\mathrm{z}$ jednym ze wskazanych powyżej rodzajów posiadania, tj. z posiadaniem samoistnym (art. 3 ust. 1 pkt 2 i ust. 3 u.p.o.l.). Warto w tym kontekście wyraźnie zaakcentować, że przeniesienie obowiązku podatkowego z właściciela (jeżeli nie jest nim Skarb Państwa lub jednostka samorządu terytorialnego) na posiadacza następuje tylko i wyłącznie wówczas, gdy to posiadanie

${ }_{30}$ J. Ignatowicz, Ochrona..., s. 76.

31 A. Sylwestrzak, Użytkowanie. Konstrukcja prawna, Warszawa 2013, s. 178. 
ma charakter samoistny. Takiego przejścia obowiązku podatkowego nie wywołuje posiadanie zależne.

Odnosząc powyższe na grunt stanu faktycznego wykreowanego poprzez zawarcie umowy przewłaszczenia nieruchomości na zabezpieczenie, zauważyć należy, że podmiotowość podatkowoprawną w zakresie podatku od nieruchomości uzyskuje ta strona umowy, która włada nieruchomością w taki sposób w jaki czyni to właściciel. Dla ustalenia, która z nich (wierzyciel czy dłużnik) sprawuje ten rodzaj władztwa, niezbędne jest zatem przyjrzenie się elementom charakterystycznym treści prawa własności. Jedynie przez pryzmat tego prawa podmiotowego można bowiem wskazać atrybuty władztwa właścicielskiego. Ustalenie treści prawa własności pozwoli ustalić treść pojęcia posiadania samoistnego, skoro odbiciem tegoż właśnie prawa jest posiadanie samoistne ${ }^{32}$.

\section{Zakres prawa własności}

Definicję prawa własności zawiera art. 140 k.c., według którego w granicach określonych przez ustawy i zasady współżycia społecznego właściciel może, z wyłączeniem innych osób, korzystać z rzeczy zgodnie ze społeczno-gospodarczym przeznaczeniem swego prawa, w szczególności może pobierać pożytki i inne dochody z rzeczy. W tych samych granicach może rozporządzać rzeczą.

Wskazane w powyższym przepisie uprawnienia (możliwość korzystania z rzeczy i rozporządzania rzeczą) określane są w doktrynie jako pozytywna strona własności, zaś wynikający z niego obowiązek innych osób nieingerowania w sferę uprawnień właściciela jako negatywna strona własności ${ }^{33}$.

Warto w tym miejscu zauważyć, że dwa typy uprawnień właściciela, o których mowa $\mathrm{w}$ we wskazanym powyżej przepisie, tj. uprawnienie do korzystania z rzeczy i uprawnienie do rozporządzania rzeczą, nie stanowią wyliczenia wyczerpującego. Regulacja kodeksowa ma tu bowiem, jak można zauważyć, charakter otwarty i dokonanej klasyfikacji nie zamyka ${ }^{34}$. Korzystanie z rzeczy i rozporządzanie nią stanowią najogólniejsze określenie uprawnień przysługujących właścicielowi i dlatego nie mogą być traktowane jako taksatywne wyliczenie,

\footnotetext{
${ }_{32}$ S. Kołodziejski, Posiadanie samoistne, zależne i służebne, „Palestra” 1966, nr10/12 , s. 36.

${ }_{33}$ Zob. np.: W. Szydło, Kodeks cywilny. Komentarz, wyd. 7, red. E. Gniewek, P. Machnikowski, Warszawa 2016, s. 296.

${ }^{34}$ W. Szydło, Kodeks..., s. 303.
} 
czy też niekompletna triada uprawnień. Pobieranie pożytków i innych dochodów jest tylko przykładowym wyliczeniem ${ }^{35}$.

Tradycyjna koncepcja zakładająca, że pozytywną stronę własności wyczerpuje tzw. triada uprawnień właściciela: prawo rozporządzania rzeczą (ius disponendi); prawo korzystania z rzeczy (ius utendi - fruendi); prawo posiadania rzeczy (ius possidendi), nie wyczerpuje więc - w świetle art. 140 k.c. - w sposób zupełny wszystkich uprawnień właściciela, stanowi jedynie przykładowe wymienienie tychże uprawnień. Należy też uwzględnić dalszą ewentualność występowania uprawnień nie mieszczących się we wskazanej triadzie ${ }^{36}$. Doktryna prawa cywilnego jest bowiem zgodna co do tego, że wyliczenie wszelkich uprawnień właściciela w sposób pełny i zamknięty byłoby trudne, czy wręcz niemożliwe, zwłaszcza wobec faktu, że uprawnienia te mogą mieć różny charakter, od uprawnień do określonych działań (także zaniechań) faktycznych, po działania prawne. W związku z tym, jak się podkreśla, przy konstruowaniu pozytywnej treści prawa własności można posłużyć się swoistym domniemaniem uprawnień na korzyść właściciela. Co oznacza, że jeżeli mamy rozstrzygnąć, czy konkretny atrybut (czy to ze sfery faktycznej lub prawnej) przysługuje właścicielowi, to należy domniemywać, że służy on właścicielowi, chyba że z przepisu szczególnego wynikałby wniosek przeciwny ${ }^{37}$.

Istotna cecha prawa własności wyraża się w tym, iż pod względem treści jest najszerszym i najpełniejszym prawem podmiotowym spośród wszystkich praw rzeczowych. Ma ono zapewnić właścicielowi dopuszczalną w danych warunkach pełnię władzy względem rzeczy ${ }^{38}$. Prawo własności obejmuje bowiem w zasadzie wszelkie możliwe uprawnienia do rzeczy ${ }^{39}$. Wszakże dalsze prawa rzeczowe są już prawami na rzeczy cudzej, stanowią formy pochodne od prawa własności. Obejmują więc swą treścią węższy, oznaczony krąg uprawnień wskazanych osób trzecich wobec danej rzeczy. Równocześnie ograniczają w tym zakresie cudze prawo własności ${ }^{40}$.

35 T. Dybowski, Ochrona własności w polskim prawie cywilnym (rei vindicatio - action negatora), Warszawa 1969, s. 60-61).

36 E. Gniewek, Kodeks cywilny. Własność i inne prawa rzeczowe. Komentarz, Kraków 2001, s. 54.

37 A. Cisek, Podstawy prawa cywilnego i handlowego, red. E. Gniewek, Wrocław 1998, s. 183-184, Jarosz-Żukowska, Konstytucyjna zasada ochrony własności, Kantor Wydawniczy Zakamycze 2003, s. 212.

38 Wyrok SN z dnia 14 listopada 2003 r., V CK 419/02.

${ }_{39}$ S. Wójcik, Zagadnienia cywilistyczne własności prywatnej [w:] Własność prywatna, red. T. Wawak, Kraków 1993, s. 326.

40 E. Gniewek, Kodeks..., Kraków 2001, s. 52. 


\section{Posiadanie samoistne a posiadanie zależne}

Według jednego z wyrażonych $\mathrm{w}$ doktrynie poglądów „posiadanie rzeczy w rozumieniu art. 336 k.c. jest niejako klamrą spinającą posiadanie samoistne i zależne, które zewnętrznie biorąc quoad corpus niczym właściwie się nie różnią. Różnica uwidacznia się dopiero przy analizie ich treści wewnętrznej, czyli in animo"s1.

W odniesieniu do konstatacji zawartej w drugiej części pierwszego z cytowanych powyżej zdań, zauważyć należy, że jest ona właściwa i trafna w przypadku porównania posiadania zależnego rzeczy $\mathrm{z}$ takim posiadaniem samoistnym dotyczącym innej rzeczy, w którym nie nastąpiło oddanie przedmiotu posiadania $\mathrm{w}$ posiadanie zależne, wówczas rzeczywiście - $\mathrm{z}$ punktu widzenia postronnego obserwatora - władztwo faktyczne sprawowane przez posiadacza zależnego może nie różnić się od władztwa faktycznego wykonywanego przez posiadacza samoistnego.

W przypadku jednak porównania posiadania zależnego z tym konkretnym posiadaniem samoistnym, z którego wywodzi się to posiadanie zależne (tj. wówczas gdy dana rzecz znajduje się we władaniu zarówno posiadacza samoistnego jak i zależnego), w zewnętrznej, widocznej dla otoczenia powłoce, mogą objawiać się różnice $\mathrm{w}$ manifestacji tych odrębnych form posiadania. Oddanie - $\mathrm{z}$ woli posiadacza samoistnego - rzeczy w posiadanie zależne, oznacza bowiem najczęściej wycofanie się posiadacza samoistnego $\mathrm{z}$ bezpośredniego, w sensie fizycznym, kontaktu z rzeczą na korzyść posiadacza zależnego. Z zewnątrz może wówczas w ogóle nie być dostrzegalne władztwo sprawowane przez posiadacza samoistnego, co mogłoby spowodować wrażenie utraty posiadania przez posiadacza samoistnego. Okoliczność ta jednak ani nie ogranicza jego posiadania właścicielskiego, ani tym bardziej takiego posiadania go nie pozbawia. Taka sytuacja nie unicestwia ponadto $\mathrm{w}$ szczególności sprawowanego przez posiadacza samoistnego władztwa faktycznego nad rzeczą, które - jak zgodnie podkreśla się w doktrynie i orzecznictwie - nie musi być efektywnie i stale wykonywane. Wystarczy rzeczywista, bieżąca, wciąż występująca możliwość faktycznego władania rzeczą. Posiadacz zachowujący się biernie nie traci przez to posiadania. Pozostaje wciąż posiadaczem, dopóki ma realną i aktualną możliwość wykonywania władztwa. Nie jest również konieczny fizyczny stały kontakt posiadacza z rzeczą, o czym

${ }^{41}$ S. Kołodziejski, Posiadanie..., s. 35. 
przekonuje art. 337 k.c., zgodnie z którym posiadacz samoistny nie traci posiadania przez to, że oddaje drugiemu rzecz w posiadanie zależne ${ }^{42}$.

Warto ponadto zauważyć, że cechą charakterystyczną posiadania zależnego jest jego współistnienie z posiadaniem samoistnym, któremu jest podporządkowane. Posiadacz zależny uznaje prawa innej osoby, co nadaje temuż posiadaniu właśnie charakter posiadania zależnego ${ }^{43}$. „Nabycie i istnienie posiadania zależnego jako takie jest uzależnione od istnienia posiadania samoistnego, w pewnym sensie "nadrzędnego« nad zależnym, o szerszym z reguły zakresie i treści”" ${ }^{34}$.

Specyfika posiadania zależnego sprawia, że z reguły wywodzić się ono będzie $\mathrm{z}$ umów dwustronnych, zawieranych pomiędzy posiadaczem samoistnym z jednej strony a posiadaczem zależnym $\mathrm{z}$ drugiej strony ${ }^{45}$. Dla porządku wskazać przy tym jednak wypada, że „każde posiadanie, a więc również i posiadanie zależne, jest władztwem faktycznym w zakresie określonego prawa (własności, innego prawa i służebności), a więc jest stanem faktycznym niezależnie od jego podstawy prawnej, która może z nim być zbieżna, ale też równie dobrze się z nim mijać. Tę podstawową zasadę wyraża art. 336 k.c. mówiąc, że posiadaczem zależnym jest ten, kto faktycznie włada jak użytkownik itd. Powołany przepis z góry zatem zakłada możliwość tego rodzaju stanu faktycznego, który może bądź to nie być zbieżny z podstawą prawną, bądź też jej w ogóle nie mieć. Jest to więc władztwo faktyczne w zakresie prawa, różnego od prawa własności i służebności, na cudzej rzeczy" ${ }^{46}$. Bezsprzecznie jednak posiadanie zależne, istniejące jako czysty stan faktyczny wyobcowany od woli posiadacza samoistnego, będzie rzadkim wypadkiem $^{47}$.

\section{Stan posiadania wynikający z umowy przewłaszczenia nieruchomości na zabezpieczenie}

Chociaż posiadanie jest związane $\mathrm{z}$ faktycznym władztwem nad rzeczą w zakresie oznaczonego prawa i nie musi mieć podstawy prawnej tegoż władania, to ustalenie charakteru władztwa może wymagać odwołania się do podstawy objęcia rzeczy we władanie. Niewątpliwie ze względu na opisaną powyżej specyfikę posiadania

\footnotetext{
${ }_{42}$ A. Kunicki, System..., s. 833, M. Warciński, Ochrona posiadania nieruchomości i stużebności gruntowych, Prawo w działaniu 2013, t. 15, s. 224.

${ }^{43}$ S. Kołodziejski, Posiadanie..., s. 40.

${ }^{44}$ K. Zaradkiewicz, Romańska teoria posiadania a kodeks cywilny, „Studia Iuridica”, t. 64, s. 108.

45 S. Kołodziejski, Posiadanie..., s. 42.

46 S. Kołodziejski, Posiadanie..., s. 42.

47 Ibidem, s. 42.
} 
zależnego jest to w szczególności konieczne w przypadku objęcia rzeczy w posiadanie na podstawie stosunku prawnego łączącego posiadacza $\mathrm{z}$ właścicielem lub posiadaczem samoistnym. W ślad za postanowieniem Sądu Najwyższego z dnia 11 października 2013 r., I CSK 5/13, wskazać należy, że ważne jest wówczas rozważnie jaki jest charakter wykreowanego stosunku prawnego, jego granice czasowe oraz rodzaj wynikającego z niego posiadania. Dysponowanie nieruchomością na podstawie stosunków prawnych oddających ją w posiadanie zależne podważa bowiem domniemanie samoistności posiadania. W takim wypadku zmiana charakteru posiadania, jakkolwiek możliwa, wymaga wykazania przez posiadacza, że jego władztwo nad rzeczą oderwało się od zakresu przekazanych mu uprawnień i stało się samoistnym, właścicielskim, niezależnym od istniejących stosunków umownych.

Z pewnością więc w przypadku ustalania jaki rodzaj posiadania przysługuje każdej ze stron umowy przewłaszczenia nieruchomości na zabezpieczenie, konieczne jest odwołanie się do wynikających z tej umowy skutków obligacyjnych i rzeczowych. Najistotniejszymi - z punktu widzenia stanu posiadania nieruchomości - następstwami zawarcia takiej umowy są:

- przeniesienie własności nieruchomości z dłużnika na wierzyciela,

- powstanie po stronie wierzyciela zobowiązania do powrotnego przeniesienia własności po spłaceniu przez dłużnika kredytu lub pożyczki,

- pozostawienie nieruchomości we władaniu dłużnika.

Z powyższego wynika, że stan prawny nieruchomości, po zawarciu umowy przewłaszczenia nieruchomości na zabezpieczenie, wygląda następująco: wierzyciel jest jej właścicielem, zaś dłużnik użytkownikiem nieposiadającym prawa własności. Powstało więc typowe dla posiadania zależnego współistnienie dwóch rodzajów posiadania. Należy w tym miejscu zauważyć, że sprzeczne z zasadami logicznego rozumowania byłoby przyjęcie tezy, że wierzyciel nabywając prawo własności nieruchomości (nawet wówczas gdy czyni to tylko na potrzeby zabezpieczenia pożyczki) nie staje się w ogóle jej posiadaczem. Regułą jest bowiem, że każda osoba nabywając własność rzeczy obejmuje wszystkie związane z tym prawem uprawnienia, zarówno te przysługujące jej od strony pozytywnej jak i negatywnej. Przy czym uprawnienie do posiadania należy do podstawowych prerogatyw właściciela. Posiadanie jest wręcz naturalną cechą prawa własności. W pierwszym więc rzędzie posiadaczem samoistnym jest właściciel władający rzeczą na podstawie przysługującego mu prawa własności ${ }^{48}$. Warto w tym miejscu przytoczyć

${ }^{48}$ W. Szydło, Kodeks..., s. 306. 
trafne w tym względzie spostrzeżenie J. Zielonackiego, zgodnie z którym „zamiar nabycia własności nie jest bynajmniej koniecznym do nabycia posiadania, ale naturalnie, kto ten zamiar ma, ten też nabywa posiadanie animo, bo w zamiarze nabycia własności mieści się eo ipso zamiar nabycia posiadania. Zamiar nabycia własności nie wyłącza zamiaru nabycia posiadania, owszem idzie tamten dalej niż ten ostatni. Jak ten, kto ma trzy, ma tem samem i dwa, tak samo też mający wolę nabyć własność, ma wolę i nabyć posiadanie. Własność bowiem upoważnia właściciela do władania fizycznie rzeczą, to jest mówiąc językiem prawniczym do posiadania jej, z czego wynika, że chcieć mieć własność bez posiadania byłoby logiczną sprzecznością"49.

Nie sposób zatem uznać, aby osoba zainteresowana posiadaniem prawa własności rzeczy, nabywała tylko sam tytuł prawny (jako nudum ius) bez związanych z nim uprawnień, co oznaczałoby $\mathrm{w}$ istocie bezprzedmiotowość uzyskanego prawa własności i pozbawieniem go wartości majątkowej, a także implikowałby tezę o pozorności czynności prawnej nabycia własności. Bez wątpienia jednak intencją wierzyciela, nabywającego własność nieruchomości na zabezpieczenie, nie jest objęcie bezużytecznego prawa, lecz uzyskanie i utrzymanie - w okresie obowiązywania umowy przewłaszczenia - „pełnowartościowego” prawa własności, o czym najlepiej świadczą czynione między nim a dłużnikiem ustalenia dotyczące przewłaszczonej nieruchomości (takie jak pozostawienie nieruchomości w posiadaniu /zależnym/ dłużnika, tj. we władaniu niestanowiącym zagrożenia utraty ani prawa własności, ani posiadania samoistnego, oraz zobowiązanie się do powrotnego przeniesienia własności po spłacie wierzytelności). Podkreślić przy tym należy także, że wierzyciel nie brałby udziału w tych ustaleniach, gdyby nie korzystał z nabytych uprawnień właścicielskich i nie uważał się za uprawnionego do decydowania o nieruchomości, czyli nie wykazywał woli władania ,jak właściciel”.

Warto w kontekście powyższego zauważyć, że nawet nabycie prawa własności $\mathrm{w}$ celu zabezpieczenia pożyczki polega $\mathrm{w}$ istocie na wykorzystaniu przez wierzyciela wartości użytkowej i wymiennej/rynkowej nieruchomości. Zrozumiałym jest przy tym, że jeżeli pożyczkobiorca nie spłaci długu, wierzyciel nie „odda” mu (tj. pożyczkobiorcy) praw właścicielskich do przewłaszczonej nieruchomości, nie ustąpi swego animus domini. Przez cały okres obowiązywania umowy właściciel nieruchomości jest zatem również ich posiadaczem samoistnym, świadomym

${ }_{49}$ J. Zielonacki, Nauka o posiadaniu i o zasiedzeniu własności według prawa rzymskiego, Lwów 1862, s. 54. 
tego, że do czasu powrotnego przeniesienia prawa własności na poprzedniego właściciela (co jednak - w sytuacji niewywiązania się pożyczkobiorcy z warunków umowy - może wcale nie nastąpić), tylko jemu przysługuje prawo własności i nie musi liczyć się z uprawnieniami innej osoby, która miałaby status właściciela tychże nieruchomości. Natomiast jego zgoda na pozostawienie nieruchomości w posiadaniu (zależnym) pożyczkobiorcy jest jednym z przejawów sprawowanego przez niego władztwa właścicielskiego. Bez uszczerbku dla posiadania samoistnego pozostaje bowiem - o czym była mowa powyżej - oddanie rzeczy w posiadanie zależne. Bez wątpienia poczynione przez wierzyciela dyspozycje dotyczące nabytego mienia, nie stanowią przejawu władztwa nad cudzą rzeczą, lecz oznakę władztwa sprawowanego zgodnie z prawem przysługującym właścicielowi, czyli jak właściciel, co świadczy o samoistnym posiadaniu.

Spoglądając na stan faktyczny powstały po zawarciu umowy przewłaszczenia nieruchomości na zabezpieczenie od strony dłużnika, można w zasadzie tylko powiedzieć, ̇̇e już samo dysponowanie (przez pożyczkobiorcę/kredytobiorcę) nieruchomością na podstawie stosunku prawnego oddającego ją w posiadanie zależne podważa domniemanie samoistności posiadania po stronie dłużnika. Przywołać tutaj warto powszechnie przyjmowany w orzecznictwie pogląd, że „rodzaj posiadania (samoistne lub zależne) zdeterminowany jest przede wszystkim zakresem faktycznego władztwa nad rzeczą oraz faktem, czy odbywa się ono za wyraźną lub dorozumianą zgodą innej osoby (w tym właściciela). Posiadanie samoistne to władztwo nad rzeczą z wyłączeniem innych osób i niezależne od wyraźnej lub dorozumianej zgody innej osoby, w tym w szczególności niezależne od zgody i woli właściciela (...) Dla oceny rodzaju posiadania ma więc znaczenie czy posiadacz objął rzecz w posiadanie $\mathrm{z}$ woli właściciela i na zasadach przez niego określonych, czy też niezależnie od woli właściciela, lub nawet wbrew jego woli czy świadomości. Objęcie rzeczy w posiadanie za zgodą właściciela, nawet tylko dorozumianą i posiadanie jej w zakresie przez właściciela określonym lub tolerowanym, świadczy z reguły o posiadaniu zależnym, choćby posiadacza z właścicielem nie łączył żaden stosunek prawny. Posiadacz włada wtedy rzeczą “jak” osoba mająca prawo, z którym łączy się określone władztwo nad rzeczą i zgodnie $z$ art. 336 k.c. jest posiadaczem zależnym" ${ }^{50}$.

W świetle powyższego wyraźnie widać, że wzajemne relacje, ukształtowane przez strony umowy przewłaszczenia na zabezpieczenie, pozwalają uznać poprzedniego właściciela nieruchomości (dłużnika) za posiadacza samoistnego

50 Postanowienie SN z dnia 4 kwietnia 2012 r., sygn. I CSK 360/11. 
przewłaszczonego mienia tylko do czasu przeniesienia prawa jego własności na wierzyciela i chociaż po tym zdarzeniu zachowuje on (dłużnik) przedmiotowe nieruchomości we władaniu, to nie już jako posiadacz samoistny, lecz zależny. Nie można bowiem mówić o posiadaniu samoistnym w sytuacji, gdy musi się liczyć z uprawnieniami właścicielskimi innej osoby. Dłużnik zachowuje uprawnienie do władania zbytą nieruchomością tylko dlatego, że nowy właściciel wyraża na to zgodę w umowie i nie ingeruje w jej posiadanie, gdyż chwilowo nie jest tym zainteresowany ${ }^{51}$.

Przypomnieć ponownie wypada, że nieodzowną cechą posiadania samoistnego jest władanie jak właściciel. Jak wskazał Sąd Najwyższy w wyroku z dnia 19.12.2000 r., sygn. V CKN 164/00, „posiadacz samoistny to taki tylko, którego zakres faktycznego władania rzeczą (...) jest taki sam, jak właściciela i który znajduje się w położeniu pozwalającym na korzystanie z rzeczy w taki sposób, jak może to czynić właściciel. Wyrazem tego jest, między innymi, niezależność w podejmowaniu decyzji co do przedmiotu posiadania; gdy decyzje te są uzależnione od zezwolenia, zgody innej osoby - o której posiadacz wie, że jest właścicielem - niweczy to możliwość uznania, że posiadacz działa w takim zakresie, jak właściciel”. Taki stan faktyczny powstaje właśnie po zawarciu omawianej umowy. Nieruchomości będące przedmiotem przewłaszczenia na zabezpieczenie pozostają bowiem we władaniu dłużnika na mocy stosunków umownych łączących go z wierzycielem. Źródłem uprawnienia dłużnika do dalszego używania owych nieruchomości jest umowa, w której określony zostaje zazwyczaj zarówno zakres tego władania jak i jego okres trwania. Posiadanie to odbywa się więc za wiedzą i zgodą właściciela, tj. wierzyciela. Natomiast fakt, że właściciel zobowiązuje się do dysponowania nieruchomością w sposób niewykraczający poza granice uzasadnione wykonaniem zabezpieczenia wierzytelności z tytułu udzielonej pożyczki lub kredytu, w związku z czym dłużnik ma zapewnioną samodzielność w korzystaniu z nieruchomości, nie oznacza bynajmniej by nieruchomości te stały się przedmiotem jego (tj. dłużnika) samoistnego posiadania ${ }^{52}$. Uzyskał on bowiem jedynie - za zgodą właściciela - faktyczne władztwo nad opisywanym mieniem, wiedząc jednocześnie, że właścicielem nie jest i nie przysługują mu związane z prawem własności prerogatywy, co niweczy możliwość uznania, że korzysta z nieruchomości w takim samym zakresie jak może czynić to właściciel. Przysługuje mu jedynie roszczenie do powrotnego przeniesienia prawa własności nieruchomości, co

\footnotetext{
51 Wyrok WSA w Krakowie z dnia 14 lipca 2017 r., I SA/Kr 486/17.

${ }_{52}$ Podobnie wyrok SN z dnia 19 grudnia 2000 r., V CKN 164/00.
} 
może jednak w ogóle nie dojść do skutku, w sytuacji niewywiązania się dłużnika ze spłaty zobowiązania.

Dodać warto również, że cechą charakterystyczną umów przewłaszczenia na zabezpieczenie jest przeniesienie posiadania $\mathrm{w}$ formie constitutum possessorium (tj. zgodnie z art. 349 k.c.), polegającej na tym, iż przeniesienie posiadania samoistnego następuje w ten sposób, że dotychczasowy posiadacz samoistny zachowuje rzecz w swoim władaniu jako posiadacz zależny (albo jako dzierżyciel) na podstawie ustalonego przez strony stosunku prawnego ${ }^{53}$. Przy zastosowaniu tej konstrukcji prawnej nie zmienia się istota posiadania polegająca na władaniu w sensie fizycznym. Dotychczasowy posiadacz samoistny zachowuje bowiem rzecz, lecz włada nią już w inny - zależny sposób, natomiast obejmujący we władanie nie był dotychczas posiadaczem i obejmuje władanie we wszystkich sferach przysługujących właścicielowi ${ }^{54}$. Aspekt ten uwypukla dodatkowo znaczenie stosunków umownych dla oceny rodzaju posiadania. Świadczy o tym, że posiadanie może powstać i zgasnąć nie tylko wskutek zmian materialnych, ale również w wyniku zmiany czynnika woli ${ }^{55}$.

Gwoli uzupełnienia powyższych spostrzeżeń oraz mając na uwadze szczególne powołane w wyroku Wojewódzkiego Sądu Administracyjnego w Lublinie z dnia 13 stycznia 2015 r., I SA/Lu 783/15 - okoliczności, mające świadczyć o niemożności przypisania wierzycielowi statusu posiadacza samoistnego, dodać należy, że o posiadaniu samoistnym nie decyduje sama tylko długotrwałość posiadania, która nie jest kryterium odróżniającym posiadanie samoistne od zależnego, ale sposób wykonywania władztwa nad nieruchomością ${ }^{56}$. Tym samym „założony tymczasowy charakter" przewłaszczenia, jak również brak po stronie nabywcy zainteresowania uzyskania prawa własności nieruchomości na stałe, nie stanowi wyznacznika przesądzającego o rodzaju posiadania. Podobnie istota i wyłącznie gwarancyjny cel umowy przewłaszczenia nie może zaprzeczyć zaistniałemu na skutek zawarcia takiej umowy stanowi posiadania, które - jeżeli z postanowień umowy wynika, że nowy właściciel nieruchomości (wierzyciel) pozostawia ją we władaniu pożyczkobiorcy (przewłaszczającego) - przysługuje dwóm podmiotom, tj. wierzycielowi (posiadanie samoistne) i przewłaszczającemu (posiadanie zależne). Tylko oderwanie się posiadacza zależnego od relacji zależności łączącej

\footnotetext{
${ }_{53}$ Zob. A. Wójcik, Przewłaszczenie..., s. 38, J. Gołaczyński, Przewłaszczenie ruchomości..., s. 61.

54 Postanowienie SN z dnia 12 marca 2008 r., I CSK 458/07.

55 A. Kunicki, System..., s. 831.

${ }^{56}$ Zob. wyrok SA w Białymstoku z dnia 22 października 2015 r., I ACa 529/15.
} 
go $\mathrm{z}$ właścicielem nieruchomości mogłoby zmienić charakter posiadania na samoistne, niezależne od istniejących stosunków umownych.

\section{Przewłaszczenie własności nieruchomości na zabezpieczenie a podmiotowość podatkowoprawna w podatku od nieruchomości}

Przechodząc do docelowego aspektu powyższych ustaleń, czyli kwestii wpływu umowy przewłaszczenia własności nieruchomości na zabezpieczenie na kwalifikację podmiotowości podatkowoprawnej w podatku od nieruchomości, w pierwszej kolejności należy podkreślić, że krąg podmiotów uzyskujących status podatników tego podatku wyznacza wyłącznie ustawa o podatkach i opłatach lokalnych, a dokładniej jej art. 3. Stosownie do treści ustępu 1 tego przepisu obowiązkowi podatkowemu podlegają osoby fizyczne, osoby prawne, jednostki organizacyjne, w tym spółki nieposiadające osobowości prawnej, będące:

1) właścicielami nieruchomości lub obiektów budowlanych, z zastrzeżeniem ust. 3;

2) posiadaczami samoistnymi nieruchomości lub obiektów budowlanych;

3) użytkownikami wieczystymi gruntów;

4) posiadaczami nieruchomości lub ich części albo obiektów budowlanych lub ich części, stanowiących własność Skarbu Państwa lub jednostki samorządu terytorialnego, jeżeli posiadanie:

a) wynika z umowy zawartej z właścicielem, Krajowym Ośrodkiem Wsparcia Rolnictwa lub z innego tytułu prawnego, z wyjątkiem posiadania przez osoby fizyczne lokali mieszkalnych niestanowiących odrębnych nieruchomości,

b) jest bez tytułu prawnego, $\mathrm{z}$ zastrzeżeniem ust. 2 (tj. z zastrzeżeniem dotyczącym przedmiotów opodatkowania wchodzących w skład Zasobu Własności Rolnej Skarbu Państwa lub będących w zarządzie Państwowego Gospodarstwa Leśnego Lasy Państwowe).

W ustępie 3 omawianego przepisu została zawarta istotna norma kolizyjna, znajdująca zastosowanie w sytuacji wypełnienia się jednocześnie, w odniesieniu do danego przedmiotu opodatkowania i różnych podmiotów, dyspozycji zawartej zarówno w punkcie pierwszym jak i drugim wskazanego powyżej art. 3 ust. 1 u.p.o.l., tj. w przypadku gdy tytuł własności i posiadanie samoistne nie zbiegają się w jednym podmiocie. Norma ta sprawia, że w takiej sytuacji nie jest możliwe równorzędne traktowanie właściciela i posiadacza samoistnego jako podatników podatku od nieruchomości lub dokonanie swobodnego wyboru jednego z nich jako adresata obowiązku podatkowego. Stanowi ona bowiem, że status podatnika uzyskuje wówczas wyłącznie posiadacz samoistny. Jej powiązanie z treścią art. 3 
ust. 1 pkt 1 u.p.o.l. pozwala jednocześnie stwierdzić, że właściciel danego przedmiotu opodatkowania będzie zobowiązany do zapłaty podatku od nieruchomości tylko wtedy, gdy pozostaje on równocześnie samoistnym posiadaczem tego przedmiotu opodatkowania (tj. wówczas gdy tytuł własności i stan faktycznego posiadania związane są z tym samym podmiotem $)^{57}$. Z taką sytuacją mamy do czynienia właśnie w przypadku zawarcia umowy przewłaszczenia nieruchomości na zabezpieczenie. Jak wynika bowiem z dokonanych powyżej ustaleń, prawo własności i posiadanie samoistne zbiegają się w osobie wierzyciela, co oznacza, że to on, a nie dłużnik (będący tylko posiadaczem zależnym) nabywa status podatnika podatku od nieruchomości.

Dla porządku warto wskazać, że ustawa o podatkach i opłatach lokalnych nakłada obowiązek podatkowy na posiadacza zależnego, tylko wówczas gdy jest on posiadaczem nieruchomości lub ich części albo obiektów budowlanych lub ich części, stanowiących własność Skarbu Państwa lub jednostki samorządu terytorialnego, co wynika $\mathrm{z}$ art. 3 ust. 1 pkt 4 u.p.o.l. Wprawdzie w przepisie tym ustawodawca w odróżnieniu od posiadania samoistnego nie używa określenia posiadacz zależny, jednakże ze wskazanych tam regulacji określających podstawy prawne władania (umowa lub inny tytuł prawny) wynika, że o ten rodzaj posiadania chodzi $^{58}$. W przypadku posiadania nieruchomości niestanowiących własności Skarbu Państwa lub jednostki samorządu terytorialnego, posiadacz zależny nie może być zatem podmiotem podatku od nieruchomości. Ujmując tę kwestię inaczej - i uwzględniając kontekst przewłaszczenia nieruchomości na zabezpieczenie - należy zauważyć, iż dłużnik, jako posiadacz zależny, mógłby zostać adresatem obowiązku podatkowego, wyłącznie wówczas gdyby właścicielem przewłaszczonej nieruchomości (wierzycielem) był Skarb Państwa lub jednostka samorządu terytorialnego. W przypadku innych wierzycieli taka możliwość nie istnieje.

Należy zwrócić uwagę również na to, że występujące w umowach przewłaszczenia nieruchomości na zabezpieczenie klauzule, zobowiązujące dłużnika do ponoszenia wszelkich kosztów i opłat związanych z przewłaszczonym mieniem, nie mogą wywrzeć żadnych skutków w zakresie obowiązków podatkowych, ani powodować zmian w istniejącym czy też mającym powstać stosunku podatkowym ${ }^{59}$.

\footnotetext{
57 Zob. wyrok WSA w Gdańsku z dnia 19 czerwca 2008 r., I SA/Gd 983/07,

${ }_{58}$ Nawet w przypadku posiadania bez tytułu prawnego, wymienionego w art. 3 ust. 1 pkt 4 lit. b u.p.o.l, chodzi o bezprawne posiadanie zależne - zob. szerzej L.Etel, Posiadacz bez tytułu prawnego jako podatnik podatków od nieruchomości, PPLiFS 2013, nr 11, s. 6 i 7.

59 Wyrok NSA w Krakowie z dnia 25 listopada 1992 r., SA/Kr 1838/92.
} 
„Obowiązek podatkowy w danym podatku - jest kategorią prawną i faktyczną zobiektywizowaną. Oznacza to, iż powstaje on w warunkach przez prawo określonych, niezależnie od woli podmiotów podlegających temu obowiązkowi, czy też podmiotów ustawowo zobowiązanych do stosowania różnych środków jego realizacji (..). Treść obowiązku podatkowego wyznaczają normy prawne dotyczące danego podatku, określające zarówno przedmiotowy jak i podmiotowy zakres podatku, zasady ustalania podstawy opodatkowania, stosowania stawek podatkowych, ulg i zwolnień itp. Wskazać trzeba, iż spełnienie przez podmiot określonych $\mathrm{w}$ ustawie warunków powstania obowiązku podatkowego prowadzi do indywidualizacji obowiązku podatkowego. Tak więc podmiot, w stosunku do którego zindywidualizował się obowiązek podatkowy, staje się w istocie rzeczy podmiotem zobowiązania (podatnikiem) w danym podatku"60.

Podkreślić przy tym należy, że zasada wyłączności ustawy w kształtowaniu obowiązku podatkowego znalazła swoje normatywne odzwierciedlenie w art. 217 Konstytucji Rzeczypospolitej Polskiej ${ }^{61}$, zgodnie z którym nakładanie podatków, innych danin publicznych, określanie podmiotów, przedmiotów opodatkowania i stawek podatkowych, a także zasad przyznawania ulg i umorzeń oraz kategorii podmiotów zwolnionych od podatków następuje w drodze ustawy. Przepis ten podniósł zatem powyższą zasadę do rangi normy konstytucyjnej.

Treść stosunku zobowiązaniowego w prawie podatkowym nie może być zatem kształtowana przez jego strony, jako swego rodzaju kompromis pomiędzy ich interesami, lecz wynika z woli ustawodawcy. Rola obu podmiotów stosunku zobowiązaniowego sprowadza się więc w zasadzie do realizacji norm ustaw podatkowych $^{62}$. Wszelkie obowiązki podatkowe, a także związane z nimi uprawnienia wynikać mogą tylko i wyłącznie z ustaw podatkowych i nie mogą być znoszone, zmieniane czy poszerzane umowami cywilnoprawnymi ${ }^{63}$. Powstanie podatkowoprawnego stosunku zobowiązaniowego, nie jest następstwem woli podatnika,

\footnotetext{
${ }^{60}$ Wyrok NSA w Lublinie z dnia 10 grudnia 1997 r., I SA/Lu 1192/96.

${ }^{61}$ Konstytucja Rzeczypospolitej Polskiej z dnia 2 kwietnia 1997 r. (Dz. U. Nr 78, poz. 483, z późn. zm.).

${ }^{62}$ R. Mastalski, Stosowanie prawa podatkowego, Warszawa 2008, s. 21.

${ }^{63}$ Zob. np. wyrok NSA w Krakowie z dnia 25 listopada 1992 r., SA/Kr 1838/92, wyrok NSA w Lublinie z dnia 10 grudnia 1997 r., I SA/Lu 1192/96,uchwała NSA w Warszawie z dnia 26 maja 2008 r., I FPS 8/07, wyrok WSA w Poznaniu z dnia 10 lipca 2013 r., III SA/Po 955/12, wyrok WSA w Gliwicach z dnia 21 października 2014 r., I SA/Gl 1768/13, wyrok WSA w Kielcach z dnia 29 marca 2017 r., I SA/Ke 63/17.
} 
lecz skutkiem wystąpienia u niego stanu faktycznego odpowiadającego hipotezie normy prawnej ${ }^{64}$.

Umowa przewłaszczenia nieruchomości na zabezpieczenie wywołuje zatem skutki podatkowoprawne tylko w takim stopniu w jakim tworzy podatkowo znaczący stan faktyczny, czyli taki stan, z którym ustawa podatkowa wiąże powstanie lub wygaśniecie obowiązku podatkowego. W przypadku podatku od nieruchomości umowa ta wpływa na zmianę podmiotu tego podatku, $\mathrm{z}$ racji przeniesienia prawa własności i (zbiegającego się z tym prawem) posiadania samoistnego z dłużnika na wierzyciela. Tylko z tymi stanami władania, wynikającymi z takiej umowy (jeżeli nie dotyczy ona nieruchomości stanowiących własności Skarbu Państwa lub jednostki samorządu terytorialnego), ustawa o podatkach i opłatach lokalnych wiąże bowiem okoliczność bycia podatnikiem podatku od nieruchomości. Natomiast wszelkie inne postanowienia stron umowy przewłaszczenia nieruchomości na zabezpieczenie, mające na celu odmienne, niezgodne $\mathrm{z}$ ustawą podatkową, ukształtowanie obowiązków podatkowych, nie wywołują żadnych skutków podatkowoprawnych. Wzajemne relacje kontrahentów mogą być jedynie podstawą roszczeń cywilnoprawnych, a nie uwolnienia od obowiązku podatkowego bądź jego modyfikacji ${ }^{65}$.O tym kto jest podmiotem podatku od nieruchomości zadecydował ustawodawca wyłącznie w art. 3 u.p.o.l. i żadne umowy cywilnoprawne nie mogą przenieść obowiązku podatkowego na podmiot niemieszczący się w dyspozycji tego przepisu.

\section{Podsumowanie}

Z przedstawionych rozważań wynika, że przewłaszczenie nieruchomości na zabezpieczenie, pomimo swej nietypowej przyczyny prawnej (causa cavendi), nie jest irrelewantne jeżeli chodzi o zakres władania nieruchomością przez strony dokonujące tej transakcji. Fakt bezwarunkowego przeniesienia prawa własności nieruchomości z dłużnika na wierzyciela, oznacza bowiem objęcie przez tego ostatniego wszystkich uprawnień przysługujących właścicielowi, w tym uprawnienie do posiadania nieruchomości. Daje to wierzycielowi najpełniejsze prawo do decydowania o nabytej nieruchomości i władania nią w najszerszym zakresie. Natomiast okoliczność, że zgodnie z ukształtowanym pomiędzy nim a dłużnikiem stosunkiem umownym, przewłaszczona nieruchomość pozostaje we władaniu dłużnika, co z zewnątrz wygląda jak kontynuacja sprawowanego

${ }^{64}$ R. Mastalski, Stosowanie..., s. 16, M. Kalinowski, Podmiotowość podatkowo prawna [w:] Prawo podatkowe. Teoria. Instytucje. Funkcjonowanie, red. B. Brzeziński, Toruń 2009, s. 68.

${ }^{65}$ Wyrok WSA w Warszawie z dnia 26 stycznia 2016 r., III SA/Wa 817/15. 
dotychczas przez dłużnika posiadania, nie tylko nie pozbawia wierzyciela posiadania samoistnego, ale świadczy o podjęciu przez niego czynności dyspozycyjnych w odniesieniu do nabytego mienia. Towarzyszące temu wyzbycie się przez dłużnika samodzielnego i niepodległego władztwa nad nieruchomością, nie pozwala zakwalifikować zachowanego przez niego posiadania inaczej jak tylko posiadania zależnego.

Wierzyciel obejmując prawa właścicielskie do przewłaszczonej nieruchomości, wyraża zarazem swoją wolę posiadania jak właściciel, co jest przejawem posiadania samoistnego, skutkującego uzyskaniem statusu podatnika podatku od nieruchomości. 